ćeg rada. Potom, kroz radove posvećeDOI: $10.5613 /$ rzs.44.1.6 ne povijesnoj dimenziji upućuje se na kontinuitete u značajkama kulturnog i kreativnog rada na što se često zaboravlja. Osim toga, autori/ce ističu i snažan utjecaj informacijsko-komunikacijskih tehnologija na stvaranje novih publika, novog broja (su)kreatora, dakle sveukupno veću mogućnost uključivanja većeg broja aktera u radne procese, ali ujedno i na veće mogućnosti kontrole toga rada, i nove vidove »eksploatacije« tako proizvedenih sadržaja. I konačno, u knjizi se upozorava i na nedostatke $u$ dosadašnjim metodološkim pristupima istraživanju kulturnog i kreativnog rada te se posljedično naglašava potreba za iznalaženjem novih istraživačkih postupaka. Treba na kraju spomenuti i to da su urednici uputili i na moguće nove oblike udruživanja zaposlenih u ovom području. Neki od tih oblika udruživanja zacijelo će pridonijeti i smanjivanju postojećih rodnih, klasnih, etničkih i »rasnih« nejednakosti te će doprinijeti stvaranju održivih modela kulturnog rada u budućnosti.

Jaka Primorac Institut za razvoj $i$ međunarodne odnose, Zagreb

\section{Sabrina P. Ramet (ed.) \\ Religion and Politics in Post-Socialist Central and Southeastern Europe: Challenges since 1989}

Basingstoke: Palgrave Macmillan, 2014, 336 str.

Religion and Politics in Post-Socialist Central and Southeastern Europe: Challenges since 1989 (Religija $i$ politika u postsocijalističkoj srednjoj $i$ jugoistočnoj Europi: izazovi nakon 1989.), nova knjiga koju je uredila Sabrina P. Ramet, razmatra izazove postsocijalističkih zemalja koje je prouzročilo političko uključivanje religijskih institucija. Njezin sadržaj obuhvaća dvanaest poglavlja, pogovor, reference za daljnje čitanje te kazalo imena i pojmova.

U uvodnom poglavlju »Religious Organizations in Post-Communist Central and Southeastern Europe: An Introduction« Sabrina P. Ramet razmatra uzroke raspada komunizma, društvene i religijske promjene te političko favoriziranje tradicionalnih i dominantnih crkvi. Papin poziv na reevangelizaciju, potaknut promjenama u legislativi i ponašanju (razvod, pobačaj, kontracepcija, istospolni odnosi i zajednice), doveo je do limitiranog uspjeha kod pobačaja i istospolnih odnosa i zajednica (izražena homofobija i neprijateljstvo tijekom gay prideova), ali i do simboličkog oblika gigantomanije u gradnji vjerskih objekata. U suvremenom kontekstu društva 
i vjerske zajednice susreću se s izazovima povrata nacionalizirane crkvene imovine, suradnje klera s komunističkom tajnom policijom, netolerancije i religijskog ekstremizma te religijskog obrazovanja u javnim školama. Vjere su nositelji vrijednosti, ali njihova javna politizacija može ugroziti demokraciju, slobodu misli i ponašanja.

U tekstu »The Catholic Church in Post-Communist Poland: Polarization, Privatization, and Decline in Influence« Sabrina P. Ramet razmatra slabljenje utjecaja Katoličke crkve u Poljskoj, na što su utjecali vanjski i unutrašnjih crkveni faktori. Vanjski faktori su pojavljivanje pluralizma i demokracije, šok vezan uz tržišne reforme i povezane generacijske i vrijednosne promjene. Procesi privatizacije i polarizacije očituju se u stavovima i ponašanju ljudi, sudjelovanju u životu crkve, ali se katolički i nacionalni identitet još uvijek povezuju. Unutrašnji faktori su kombinacija promoviranja vlastite crkvene agende (vjeronauk, zabrana seksualnog odgoja, restrikcije pobačaja, utjecaj na političke izbore, uz zanemarivanje socijalnih pitanja), otkriće i kontroverzije oko suradnje katoličkog klera s tajnom policijom i povrata crkvene imovine vjerskim zajednicama te loša reakcija na seksualne skandale u Crkvi.

Milan Reban u tekstu »The Catholic Church in the Post-1989 Czech Republic and Slovakia« analizira položaj Katoličke crkve u nereligioznoj Češkoj i izrazito religioznoj Slovačkoj. Ona je utjecala na promjene, ali nije dala odgovarajući odgovor zbog želje za po- novnim uspostavljanjem položaja prije 1948., uz problem suradnje klera s režimom i lustracijskog procesa. Katolička crkva u Slovačkoj uspješnija je od one u Češkoj u reguliranju odnosa crkve i države (registracija vjerskih zajednica, povratak crkvenog vlasništva, financiranje djelatnosti crkve, religijsko obrazovanje) te restrikcijama oko pobačaja i registriranog partnerstva. Zbog rane modernizacije u Češkoj više od polovine građana nije religiozno, slabi utjecaj Crkve, ali se pojavljuju alternativne religijske skupine. U Slovačkoj Crkva dominira, ali nije imuna na sekularizaciju, uz potrebu osvrta na komunističko razdoblje.

Utjecaj Kádárovog režima na Katoličku crkvu u Mađarskoj razmatra Krisztián Ungváry u tekstu »The Kádár Regime and the Subduing of the Roman Catholic Hierarchy«. Prvo je razdoblje obilježeno progonom, a nakon sedamdesetih godina uspostavljaju se bolji odnosi. Crkva je izgubila nezavisnost $\mathrm{i}$ kler je surađivao s tajnim službama, pa nakon promjene sustava oprezno djeluje. Crkva je uspjela ostvariti povratak nacionaliziranoga vlasništva kao i to da država financira njezine djelatnosti, no pred njom su još dvije teme. To su njezin odnos prema prošlosti (suradnja s tajnim službama) i prema integraciji u Europsku uniju (podržava integraciju iako naglašava opasnost liberalizma i tržišne ekonomije). U suvremenosti nedostaje praktična odvojenost crkve i države.

Egon Pelikan u tekstu »The Catholic Church and Politics in Slovenia« 
razmatra odnos Katoličke crkve i države u Sloveniji. Tijekom komunizma, ona je meta napada i kontrole UDBAe, ali tijekom šezdesetih godina odnosi zatopljavaju, a osamdesetih započinje proces demokratizacije. Crkva i Vatikan sudjelovali su u promjenama i procesu deklariranja neovisnosti Slovenije uz očekivanje povratka nacionalizirane imovine i vjeronauka $u$ javne škole te revizije događaja iz Drugoga svjetskog rata i pravnog statusa Crkve. U suvremenom razdoblju prisutno je eklezijastičko školovanje, a u državnim školama odvojenost crkve i države. Brojni su financijski izvori Crkve, ali je, zbog problematičnih investicija, mariborska nadbiskupija doživjela bankrot, a problematično je i to što je Crkva ideološki stup jednoj političkoj opciji.

$\mathrm{U}$ tekstu »Church and State in Croatia: Legal Framework, Religious Instruction, and Social Expectations« Siniša Zrinščak, Dinka Marinović Jerolimov, Ankica Marinović i Branko Ančić analiziraju odnos crkve i države u Hrvatskoj. U komunizmu su prisutne dvije faze odnosa (konfliktna i kooperativna), a osamdesetih godina nastupa revitalizacija i veća javna vidljivost religije, dok devedesetih jača povezanost religije i nacije, politizacija religije i počinje rat. Razmatra se razvoj pravnog okvira (odvojenost crkve i države, selektivna kooperacija, piramidalni model statusa vjerskih zajednica, ugovori, povratak imovine), uvođenje vjeronauka u javne škole (naglašena potpora konfesionalnom vjeronauku) te društvena percepcija i očekivanja o religiji u javnoj sferi (ne podržava se političko uključivanje crkve i nejednakost vjerskih zajednica, pitanje kako financirati vjerske zajednice), koji reflektiraju općenitu društvenu klimu i europski obrazac odnosa crkve i države. U Hrvatskoj su važni izazovi jake veze političkog režima i Crkve, arbitrarnih odluka vlade te javne rasprave o odnosu crkve i države.

Janine Natalya Clark u tekstu »The Cross, the Crescent, and the War in Bosnia: The Legacy of Religious Involvement« analizira politizaciju religije, uništavanje religijskih simbola (vjerski objekti) i religijske elemente rata (uloga stranih mudžahedina i vehabijskog pokreta u nametanju striktne interpretacije islama te način kako su religijski akteri pasivno i aktivno podupirali rat) u Bosni i Hercegovini. Ti elementi otežavaju vjerskim zajednicama suočavanje $s$ prošlošću. One se zadovoljavaju žrtvom i patnjom vlastitih zajednica, odnosno odabranim traumama, što zajedno s politizacijom religije otežava njihovu ulogu u izgradnji mira.

Povratak religije u javnu i političku sferu i ideja da je Srpska pravoslavna crkva čuvar nacije i identiteta sadržaj je teksta »Religion and Democracy in Serbia since 1989: The Case of the Serbian Orthodox Church« Radmile Radić i Milana Vukomanovića. Problem Kosova, posjet pape Srbiji i stav Srpske pravoslavne crkve prema ekumenizmu (otežavaju ga odnosi s Katoličkom crkvom i politički motiviran raskol i odnosi s pravoslavnim vjernicima u Makedoniji i Crnoj Gori, sukobi umjerenjaka i konzervativaca) otežavajuća su pitanja 
za odnos s državom. Ipak, novi zakon o pravnom položaju vjerskih zajednica iz 2006. uvodi brojne beneficije od države. Promjena zakona, liberalizacija položaja vjerskih zajednica i širenje prava i religijskih sloboda za Srpsku pravoslavnu crkvu predstavljaju izazov u suvremenim pluralnim uvjetima.

Aleksander Zdravkovski u tekstu »Islam and Politics in the Serbian Sandžak: Institutionalization and Feuds« razmatra institucionalizaciju islama $u$ Srbiji kao problem za vlasti, političke promjene i organizacijske promjene Islamske zajednice, sukobe unutar mešihata Sandžaka nakon neodobrene registracije, vehabijski izazov, te raskol između mešihata Sandžaka i Islamske zajednice Srbije. Sukobi unutar islama u Srbiji dokaz su toksičnog utjecaja politike u procesu etabliranja religijskih institucija. Potrebna je rekonstrukcija odnosa politike i religije u Srbiji te dopuštenje za postojanje dviju islamskih zajednica, a proces sekularizacije mogao bi tomu pridonijeti.

U tekstu »The Orthodox Churches of Macedonia and Montenegro: The Quest for Autocephaly« Aleksander Zdravkovski i Kenneth Morrison analiziraju povezanost pravoslavlja i nacionalizma, njihovu uključenost u politiku u Makedoniji i Crnoj Gori, posebice $\mathrm{u}$ proces stjecanja njihove neovisnosti. Srpska pravoslavna crkva blokira autokefalnost lokalnih crkvi negirajući postojanje makedonske i crnogorske nacije i taj je sukob znatno politiziran. U Makedoniji su prisutni izazovi povrata imovine, vjeronauka u školama i lustra- cijskog procesa, a u Crnoj Gori povrat imovine i pravna bitka Srpske i Crnogorske pravoslavne crkve oko vlasništva nad vjerskim objektima. Njihove se lokalne crkve suočavaju s izazovom priznavanja vlastite autokefalnosti.

»The Orthodox Churches and Democratization in Romania and Bulgaria« tekst je u kojem Lavinia Stan i Lucian Turcescu razmatraju djelovanje Rumunjske i Bugarske pravoslavne crkve tijekom demokratizacije i ulaska u EU, osobito odnos religije i postkomunističkog zakonodavstva, te religije i izborne politike. Rumunjska pravoslavna crkva utjecajan je politički akter i nema spora unutar crkve, zakon o religiji i privilegije od države zahvatili su i manje vjerske zajednice, a uvođenje vjeronauka u škole njihov je najveći uspjeh. Bugarska pravoslavna crkva doživjela je podjelu na dvije zajednice, koje podupiru domaći politički akteri, zbog pitanja suradnje klera s komunističkim režimom. Rumunjska ima jaku crkvu i manje jaku državu, a Bugarska jaču državu i manje jaku crkvu. To je rezultat njihovih razlika u povijesti, autokefalnosti crkvi, mjestu obrazovanja svećenstva tijekom komunizma te snazi nacionalizma u jačanju crkvi.

U tekstu »Religion and Politics among Albanians of Southeastern Europe« Isa Blumi razmatra položaj i izazove s kojima se susreću Albanci na Kosovu. U SFRJ je stvorena Islamska zajednica kao jedina odgovorna za muslimane, uz ukidanje derviških redova koji su stvorili ruralnu autonomiju Kosova preko svoje mreže, koju 
je i Milošević najviše napadao. Prisutna je politizacija religije u širem kontekstu prilagodbi nakon neovisnosti te raznolikost aktera uključenih u dnevne aktivnosti (kompanije, tajne službe i drugi). Zbog uništene ruralne ekonomije, marginalizacije i siromaštva postoji raznolikost izvora sukoba na Kosovu, a »etnički sukob« kao agenda omogućava politički oportunizam, uz korupciju i ekonomsku depresiju.

U pogovoru knjige Robert F. Goeckel zaključuje da se u njoj analizira pravni i institucionalni status crkvi tijekom komunističkog i tranzicijskog razdoblja, njihov odnos prema komunističkoj prošlosti, njihov ekstremizam, društvena netolerancija i reakcije protiv rodnih pitanja te jaka razina religioznosti i pripadnosti crkvi. S druge strane, u knjizi se razmatra utjecaj institucionalnih faktora. Stabilna demokracija zahtjeva jake partijske sustave, pa su tijekom razdoblja slabih stranaka crkve ispunile prazninu vlasti i predstavile zahtjeve sustavu, dok se konsolidacijom demokracije očekuje njihova veća društvena uloga, a manje politička, koju suvremene društvene okolnosti možda kod njih mogu opet pobuditi.

Ova je knjiga značajan doprinos istraživanju društvenog i religijskog konteksta odnosa crkve i države u postkomunističkoj srednjoj i jugoistočnoj Europi, izazova s kojima se suočavaju njihova društva i vjerske zajednice, uz značajnu komparativnu vrijednost istraživanih država, konfesija i tema. Stoga je ona nezaobilazna literatura za sve one koji pokazuju interes za ovo istraživačko područje.

Goran Goldberger

Institut za društvena istraživanja u Zagrebu 